\title{
The Making of the Māori Middle Ages
}

\author{
J.D. Stout Lecture 2016
}

\section{ATHOLL ANDERSON}

Literary and scientific narratives are often constructed in three parts, of which the task of the middle section is to make the beginning and the end satisfactorily consistent with each other. In this lecture I discuss some ideas about how that might be accomplished in relation to a middle or transitional phase of Māori archaeology, which I will take as dating about AD 14501650. Some of you might wonder whether this has not been done satisfactorily already, but I assure you that it has not. In fact, just as Medieval Europe was once seen as a dark age between the Classical era and its Renaissance, so the middle phase in Māori archaeology remains a shadowland between highlights of Polynesian colonisation and classic Māori culture.

This is a legacy of scholarly thought about pre-European New Zealand in which, for more than a century, no middle period or transitional phase was recognized at all. Differences between archaeological remains that seemed early, notably butchered moa bones and flaked stone tools, and those that seemed late, such as gardens, forts and nephrite ornaments, were ascribed to the quite sudden replacement of one immigrant population by another; no transition was needed. Even when archaeology became an academic discipline with the appointment of Jack Golson to Auckland University in 1954, the population replacement model of culture change in New Zealand was not entirely discarded. Golson proposed that between his early or Archaic East Polynesian phase and his late or Classic Māori phase, there should be an intermediate or transitional phase which he called "proto-Māori." But as he was unable to define it he proposed an alternative model in which Classic Māori material culture reflected late cultural replacement by an alien tradition. ${ }^{1}$

In the event, archaeologists preferred the notion of transition but could do no better with it. Wilfred Shawcross described the transitional phase as "a kind of cultural 'no-man's land' ... not possessing any artefacts by which it might be recognized," and Janet Davidson remarked similarly that arranging Māori material culture assemblages, "invariably results in a blank in the middle, and an inability to document the changes that took place."2 Plausible intermediate forms of adzes, fish hooks and ornaments were suggested, including by Shawcross himself on stylistic change in Māori combs, and more generally by Sidney Moko Mead, but the fact remained that few of the artefact types involved had been provenanced stratigraphically or by radiocarbon dating to a middle phase. ${ }^{3}$ One recent exception is worth noting. Davidson wrote in 1984 that "one new find of a chevroned pendant in a proper archaeological context would add considerably to our knowledge of [Māori] art." In 2010 a fragment of chevroned pendant, the main type of whaletooth ornament proposed as transitional, was recovered from a site in Southland and radiocarbon dated, gratifyingly, to $1450-1550 .{ }^{4}$

Such occasional success aside, the focus upon material culture as an index of transition was simply too narrow. Golson acknowledged that point in 1986, regretting that his transition phase had offered no way forward, "even though all the crucial changes must by default have taken place there." The way forward, he conceded, was through further investigation of environmental, economic and social trajectories. Of those, Douglas Yen's argument in 1961 for an experimental phase in the development of Māori horticulture had been particularly influential, indeed the core proposition for later models of Māori cultural transition. Gardening was introduced to northern New Zealand where development of over-wintering storage pits enabled expansion southward. ${ }^{6}$ Subsequent climate deterioration required agronomic adaptations such as garden walls, mounds and made soils but, eventually, abandonment of marginal districts. This climate-horticulture relationship became the key 
dynamic of culture change in regional archaeological projects by Roger Green on the Auckland province and Foss and Helen Leach on Palliser Bay. ${ }^{7}$ Faunal turnover, landscape change, population growth and the rise of warfare were added as additional processes in the transition of early to late Māori archaeology (Table 1).

\begin{tabular}{|l|l|l|}
\hline $\begin{array}{l}\text { EARLY STATE OF } \\
\text { VARIABLE: AD 1250-1450 }\end{array}$ & $\begin{array}{l}\text { INFERRED PROCESS OF } \\
\text { CHANGE: AD 1450-1650 }\end{array}$ & $\begin{array}{l}\text { LATE STATE OF VARIABLE: } \\
\text { AD 1650-1800 }\end{array}$ \\
\hline & & \\
\hline Largely original landscape & Extensive fire \& deforestation & Largely modified landscape \\
\hline Resource access throughout NZ & Increasing group territoriality & Resource access localized \\
\hline Limited internal migration & Increasing regional inequality & Frequent internal migration \\
\hline Population evenly spread in NZ & Climatic \& economic change & Population mostly northern \\
\hline Low population density & Exponential growth rate & High population density \\
\hline Southern inland settlement & Change in search image & Northern inland settlement \\
\hline Big game hunting: moa, seal & Over-hunting \& extinctions & Small game: fishing \& fowling \\
\hline Dispersed small-scale gardening & Commodification of production & Concentrated, large-scale gardening \\
\hline Undefended settlements & Rising incidence of warfare & Defended settlements \\
\hline Infrequent warfare & Increasing group competition & Frequent warfare \\
\hline Open burial at settlements & Threat of interference & Concealed burial elsewhere \\
\hline Infrequent slavery & New labour contexts & Frequent slavery \\
\hline Whanau to hapu chiefdoms & Increasing societal complexity & Hapu to iwi chiefdoms \\
\hline
\end{tabular}

Table 1: Some cultural changes through the pre-European Māori sequence, highlighting the inferred transitional processes.

Process is, of course, time-dependent, and up to 1990 archaeologists were working with chronologies that began with human colonization around $800-900$, or in some perspectives much earlier (Figure 1). In 1991, the New Zealand chronology was shortened considerably, with initial human arrival not until about $1200 .{ }^{8}$ The short chronology, however, disarticulated relationships assumed hitherto between phases and processes. Massive environmental change, earlier regarded as extending over the greater part of the sequence, now became concentrated at the beginning of the sequence; gardening seen as being adapted progressively southward now occurred in the South Island almost as early as anywhere else; population growth assumed as beginning in the ninth century or even much earlier, now had to be recalibrated to a thirteenth century start; and climate deterioration seen as beginning 500 years after initial colonization, arrived after only 100-200 years, and more abruptly. The diversity and scale of dislocation between time and process arising from the advent of the short chronology has yet to be addressed systematically by archaeologists, but I shall have to make a start on it; a karmic consequence, perhaps, for having shortened it in the first place.

In this lecture, I consider the roles of two large processes involved in re-shaping the cultural landscape during the middle phase of Māori archaeology-climate change and population growth - and then focus upon horticultural expansion and its emergent results in the form of internal migration, slavery, increasing group size and proliferating pa sites.

\section{Climate Change}

The potential influence of climate fluctuations upon Māori cultural behaviour has been raised on several occasions, for instance by Foss Leach, but recent research in climate change has brought greater clarity to the timing and nature of its affects. ${ }^{9}$ 


\begin{tabular}{|c|c|c|c|c|c|}
\hline AD & Green 1970 & Leach 1981 & $\begin{array}{l}\text { Davidson } \\
1984\end{array}$ & Bulmer 1989 & $\begin{array}{l}\text { Anderson } \\
1991 ; \\
\text { et al. } 2104\end{array}$ \\
\hline \multicolumn{6}{|l|}{1800} \\
\hline 1700 & Classic Maori & New Colonisation & Traditional & Traditional & Traditional \\
\hline 1600 & \multirow[t]{2}{*}{ Proto-Maori } & \multirow{2}{*}{$\begin{array}{l}\text { Abandonment } \\
\text { Decline }\end{array}$} & & & \\
\hline 1500 & & & & & \multirow[t]{2}{*}{ Transitional } \\
\hline 1400 & Experimental & \multirow[t]{2}{*}{ Consolidation } & \multirow{3}{*}{$\begin{array}{l}\text { Expansion } \\
\text { \& Rapid } \\
\text { Change }\end{array}$} & \multirow[t]{3}{*}{$\begin{array}{l}\text { Expansion } \\
\text { \& Change }\end{array}$} & \\
\hline 1300 & \multirow[t]{3}{*}{ Developmental } & & & & Colonisation \\
\hline 1200 & & \multirow[t]{3}{*}{ Colonisation } & & & \\
\hline 1100 & & & \multirow[t]{4}{*}{ Settlement } & \multirow[t]{2}{*}{ Settlement } & \\
\hline 1000 & \multirow[t]{2}{*}{ Settlement } & & & & \\
\hline 900 & & & & \multirow[t]{5}{*}{ Colonisation } & \\
\hline 800 & & & & & \\
\hline 700 & & & & & \\
\hline 600 & & & & & \\
\hline 500 & & & & & \\
\hline & & & & & \\
\hline
\end{tabular}

Figure 1: Chronological and processual frameworks for the archaeology of pre-European Māori. Phases in earlier frameworks are shaded according to their approximatelv equivalence to those in Anderson et al. (1991).

Change in the New Zealand climate can be understood broadly through the operation of several systems that are measured by indices of sea level air pressure. The SOI (Southern Oscillation Index) measures the state and strength of tropical circulation expressed by ENSO (El Niño Southern Oscillation) in short but frequent interventions that affect northerly and easterly winds over New Zealand. The IPO (Interdecadal Pacific Oscillation) causes similar shifts in circulation, but at multi-decadal intervals; its positive state strengthening westerlies, making northern and eastern districts relatively drier, and having the opposite effect in a negative state. IPO also modulates ENSO, weakening or strengthening its activity. The SAM (Southern Annular Mode) varies both seasonally and in the long term. It measures air pressure between 40 and $60^{\circ}$ South, which affects westerly and southerly circulation. ${ }^{10}$

These indices describe various combinations of windflow and strength, and therefore of temperature and precipitation which, in turn, can be regarded as three climatic regimes: When SOI is positive (the La Niña state) and SAM is positive, tropical air reaches New Zealand with northerlies and easterlies that block the prevailing westerly flow. When SAM remains positive but SOI is negative (the El Niño state) the zonal westerly flow is enhanced, and when SOI and SAM are both in a negative state, then conditions turn cold and unsettled with prevailing southwesterly and southerly winds. The three regimes are named respectively, 
Blocking, Zonal and Trough. ${ }^{11}$ Of course, the typical weather associated with each of these regimes is not only different overall, but also between regions in New Zealand. Briefly, the Blocking regime brings wetter conditions to the north of both islands, and to the eastern North Island and it is drier to the west. The Zonal regime brings wetter conditions to the south and west of the South Island, but drier conditions elsewhere, while the Trough regime brings wetter, cloudier and colder conditions everywhere.

Amongst many sources of evidence, research by Heidi Anne Roop on laminated sediments in Lake Ohau, south Canterbury, provides a fine-grained picture of climate variation through the period of Māori occupation (Figure 2). Blocking conditions dominated the Polynesian Warm Period up to the late fourteenth century. There was then an abrupt switch, about 1400, to Trough conditions that prevailed until 1560, becoming thereafter Zonal up to 1650. From 1650, conditions were mainly Zonal or Blocking. The Little Ice Age (LIA), in these data, spans the period 1385-1710. Additional climatic modelling and field evidence of floods and similar events indicates that Trough conditions, with the passage of frequent depressions accompanied by southerly fronts, predominated during the early part of the LIA producing conditions described as very cold, very wet, windy and cloudy in the period 1500$1650 .{ }^{12}$

These changes began at an awkward point for habitation in southern New Zealand. The first and most devastating phase of deforestation from about 1250 to 1450 had reduced most of the landscape to charred timber, scrub and tussock. ${ }^{13}$ The flush of moa-hunting had probably supported several thousand people represented by at least 255 moa-hunting sites south of Banks Peninsula. When moa became extinct about 1450 a re-orientation of subsistence economy toward fishing and foraging was necessary and, by the late-eighteenth century that also supported a southern population of several thousand. ${ }^{14}$ In the middle phase, however, the population was much smaller, as implied archaeologically. Of radiocarbondated sites within a radius of $200 \mathrm{~km}$ from Shag River Mouth, north Otago, 36 date to earlier than 1450 , but only 10 to $1450-1650 .{ }^{15}$ No large coastal settlements remained, occupation on the south coast had effectively ceased and much of the interior was abandoned. We might suspect that the descent into Trough conditions lasting from the late $14^{\text {th }}$ to late $15^{\text {th }}$ centuries, induced a population decline, perhaps including migration north.

In central New Zealand, remains of Māori gardens extend as far south as Taumutu (south of Banks Peninsula), but none in Canterbury have been radiocarbon dated. As most are associated with Ngai Tahu pa sites dated traditionally to 1700-1850 they are probably all late features. Of gardens that have radiocarbon dates, some date to the fourteenth century on the Kaikoura coast, and D'Urville Island. The largest, about 10 ha, is at Clarence river, and its age in uncertain, although marine shell samples suggest seventeenth century or later. ${ }^{16}$ Garden sites date to the fifteenth and sixteenth centuries in the Marlborough Sounds, Tasman Bay and Golden Bay and some persisted until the end of the seventeenth century in Golden Bay. ${ }^{17}$ Across Cook Strait, gardens date to the colonisation phase on the west coast of Wellington and in Horowhenua, and up to the fifteenth or early sixteenth centuries in Palliser Bay and the southeast coast of the North Island. ${ }^{18}$

Taking these data as representative, it can be suggested that kumara cultivation in the early period had reached as far south as the Kaikoura coast, and possibly to about Banks Peninsula (about $43^{0} \mathrm{~S}$ ). By the late sixteenth century it no longer existed south of about latitude $41^{0} \mathrm{~S}$ (Tasman Bay-Kapiti Coast-Castlepoint). This represents a retreat northward of around $150 \mathrm{~km}$ from Kaikoura during the middle phase. Furthermore, just as gardening was relatively scarce between its absolute southern limit and Tasman Bay, so it is probable that by the sixteenth century gardening north of the new southern limit was marginal up to southern Hawkes Bay and South Taranaki (Figure 3). 


\begin{tabular}{|c|c|c|}
\hline YEARS AD & Circulation & \\
\hline $1810-1835$ & & \\
\hline $1785-1810$ & & \\
\hline $1760-1785$ & & \\
\hline $1735-1760$ & & \\
\hline $1710-1735$ & & \\
\hline $1685-1710$ & & \multirow{13}{*}{ LITTLE ICE AGE } \\
\hline \multicolumn{2}{|l|}{ 1660-1685 } & \\
\hline \multicolumn{2}{|l|}{$1635-1660$} & \\
\hline \multicolumn{2}{|l|}{$1610-1635$} & \\
\hline \multicolumn{2}{|l|}{$1585-1610$} & \\
\hline \multicolumn{2}{|l|}{$1560-1585$} & \\
\hline \multicolumn{2}{|l|}{$1535-1560$} & \\
\hline \multicolumn{2}{|l|}{$1510-1535$} & \\
\hline \multicolumn{2}{|l|}{$1485-1510$} & \\
\hline \multicolumn{2}{|l|}{$1460-1485$} & \\
\hline \multicolumn{2}{|l|}{$1435-1460$} & \\
\hline \multirow{2}{*}{\multicolumn{2}{|c|}{$\frac{1410-1435}{1385-1410}$}} & \\
\hline & & \\
\hline \multirow{2}{*}{\multicolumn{3}{|c|}{$\frac{1360-1385}{1335-1360}$}} \\
\hline & & \\
\hline \multicolumn{3}{|l|}{$1310-1335$} \\
\hline \multicolumn{3}{|l|}{$1285-1310$} \\
\hline \multicolumn{2}{|l|}{$1260-1285$} & POLYNESIAN \\
\hline \multicolumn{2}{|l|}{$1235-1260$} & WARM PERIOD \\
\hline \multicolumn{3}{|l|}{$1210-1235$} \\
\hline \multicolumn{3}{|l|}{$1185-1210$} \\
\hline \multicolumn{3}{|l|}{$1160-1185$} \\
\hline \multicolumn{3}{|l|}{$1135-1160$} \\
\hline \multicolumn{3}{|l|}{ 1110-1135 } \\
\hline \multicolumn{3}{|l|}{$1085-1110$} \\
\hline & REGIME & CIRCULATION \\
\hline & Blocking & Northerly \\
\hline & Zonal & Southwesterly \\
\hline & Trough & Southerly-Unsettled \\
\hline
\end{tabular}

Figure 2: Climatic change (25-year intervals) at Lake Ohau, South Canterbury (after H.A. Roop 2015). 


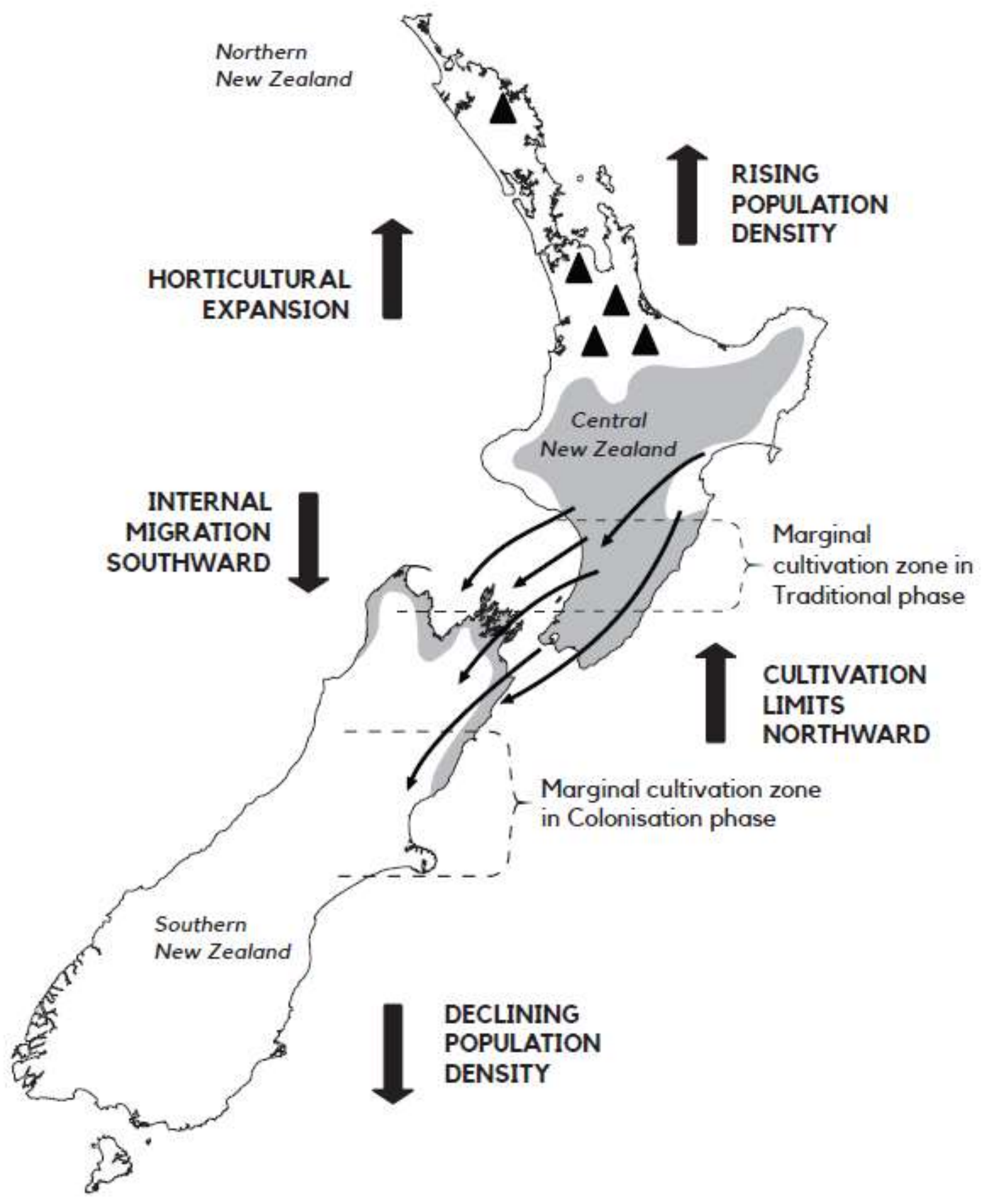

Figure 3: Processes of change during the transitional phase, c. 1450-1650. 
The loss of gardening during the middle period in most of central New Zealand seems to have involved a general decline of occupation. In Palliser Bay, the most closely-studied case, occupation appears to have ceased during the middle period. In the Marlborough Sounds, forest re-grew over gardened areas, so that when the apparently ancient trees were cut down in the $19^{\text {th }}$ century, the re-emergence to view of storage pits gave rise to a belief that these had been the house-sites of an ancient race of pre-Māori, pit-dwelling people. ${ }^{19}$

Climate change seems a plausible explanation for the retreat of gardening, if not necessarily the only one. Kumara will not produce in soil temperatures of less than $15^{\circ} \mathrm{C}$ for five consecutive months, conditions barely met in central New Zealand even today. ${ }^{20} \mathrm{~A}$ northward retreat of $150 \mathrm{~km}$ on temperature grounds implies a decline in mean annual temperature at sea level of about $1^{0} \mathrm{C}$. Looking at evidence of changing temperatures over the last millennium, it is apparent that an early period, estimated as $0.3-0.5^{0} \mathrm{C}$ warmer on average than the twentieth century, was followed by a cold period of similar deviation below the twentieth century average. This is recorded in various sources. Here are two examples. A treering record from silver pine near Hokitika shows that mean summer temperature about 14801500 was almost exactly as it is today in summer at Hokitika, about $15.5^{\circ} \mathrm{C}$, but by 1525 it had dropped to $14.0^{\circ} \mathrm{C}$, later fluctuating around $14.5^{\circ} \mathrm{C} .{ }^{21}$ An oxygen-isotope record from Hawkes Bay shows the same sharp dip in temperature at 1500 and the deterioration of the eastern North Island climate into conditions described by Andrew Lorrey and colleagues as "very wet" and "very cold." 22 A summer temperature decline through the LIA in summer of 0.8 to $1.4^{0} \mathrm{C}$ relative to today might not seem like much, but that scale of change is very similar to data recording the Little Ice Age in Europe where, of course, profound economic and social consequences have been recorded. ${ }^{23}$

\section{Population growth}

Alongside changing climate was changing population density. How influential it might have been as a transitional process depends upon where and in what way it was happening. Population growth is often modeled as density-dependent, shown by a logistic or sigmoid curve, in which it is assumed that the finite nature of resources in an environment sets an upper limit, or carrying capacity, to population density. As early rapid growth passes the half-way point of maximum population size, resource scarcity slows the growth rate until it ceases at carrying capacity. This model has been the favoured hypothesis of population growth for pre-European Polynesian and Māori demography, but is it still realistic? ${ }^{24}$

Curves of population growth history for various Pacific islands have been drawn by summing probability distributions of radiocarbon dates. This common method assumes that the stacked age-probability distributions of a large sample of radiocarbon dates describe a time trend of archaeological site frequency which, in turn, is related to population growth trends. The method is open to criticism as shown, for instance, by Bruce McFadgen and colleagues who found that the probability distribution of radiocarbon dates is heavily influenced by fluctuations in the carbon isotope production curve, used for calibrating radiocarbon dates, especially over the last 400 years. ${ }^{25}$ It is possible to take that into account, yet the resulting population curves often remain quite complex, as in radiocarbon data from Kosrae (Micronesia) and Hawai'i, where inferred population size and density increase strongly around 1300 and peak about 1500 in both cases, after which they decline significantly. ${ }^{26}$

The only graph of summed radiocarbon probability for New Zealand as a whole was constructed using a necessarily small sample of dates on marine shell, and it shows a deep trough AD 1550-1650. This probably reflects the calibration curve problem, and the authors guessed that otherwise it might have formed a sigmoid curve. Perhaps so, but a more recent graph for the Bay of Plenty, although also on a small sample of radiocarbon dates, raises another possibility. The Bay of Plenty curve indicates a significant decline in population 
beginning about $\mathrm{AD} 1600 .^{27}$ It is interesting to observe that complex population curves of this kind are now being reported elsewhere in relation to the arrival of farming. Research across western Europe, where agriculture was introduced by immigrants from the eastern Mediterranean, indicates that population responses to it were highly varied in immediacy, scale and type, with little to suggest that a logistic response, or even a simple exponential curve was at all common. Instead, there are sharp peaks and collapses in multi-modal succession. ${ }^{28}$ In the European analyses, population declines are often by 30-60\%, which is quite extraordinary. Climate change was not the cause, but the volatility of demographic responses to the advent of agriculture is clear, even if the causes are yet uncertain.

Whether the Māori population experienced similarly sharp responses to increasing reliance upon horticulture in the northern region remains unknown but it is possible. In any event, the current evidence no longer allows us to assume simple logistic or exponential growth in the presence of agricultural production. We might find that all regional curves in New Zealand are different and possibly that the total Māori population was significantly higher at some earlier point than it was at the time of European arrival.

\section{Northern horticulture}

The kind of demographic responses that I have described are only likely to have occurred where horticulture was expanding and intensifying relative to other subsistence activities. In northern New Zealand, garden features including small storage pits are dated to the early fourteenth century and horticulture probably began immediately upon colonization, 1230-1280. Gardens, pits and pa occur covariantly all around the coast of northern New Zealand, but it can be argued that it was the development of large-scale gardening in the northern interior that was especially significant for other processes. At Pouerua in the inland Bay of Islands, gardens seem to have begun with pa construction around 1550, and they covered an area of 550 ha by the end of the eighteenth century. In the Tamaki Isthmus, and adjacent South Auckland, there is hardly a distinction between coastal and inland, but cultivation of slopes on the 24 volcanic cones began in the fourteenth century and was expanding after 1500. The extent of the Tamaki cultivation areas is difficult to estimate because so many of the cones were destroyed before archaeological survey began, but several thousand ha seems possible. ${ }^{29}$

An equally large or larger area of cultivation existed in the middle Waikato basin where about 3000-4000 ha of Horotiu loams have been modified by Māori. This is the most extensive area of pre-European gardening recorded in New Zealand. ${ }^{30}$ There are some 500 gardens located close to the Waikato River and its major tributary the Waipa, and 200 pa sites nearby on the riverbanks. The gardens have characteristically modified soils that are so extensive that they are grouped as a soil sub-type "Tamahere sandy gravelly loam" (Figure 4). Their visibility is enhanced by the frequency of large borrow pits, generally about 3.0-5.0 m deep, that are seldom more than $100 \mathrm{~m}$ from the gardens. In the Waipa district, 2543 borrow pits having been recorded, although Matthew Campbell suggests that a full survey of the Waikato Basin could locate 5000 borrow pits and 1000 garden sites. ${ }^{31}$ These data indicate a former horticultural system of substantial scale.

Recent quantitative research by Warren Gumbley and colleagues is beginning to disclose the intricate organization, agronomic architecture and human effort involved. Gardens were built from scratch, by the felling or firing of primary forest, a major undertaking in its own right, and then the existing soil was modified by the addition of sands and gravels dug from beneath it in the borrow pits located near the gardens. This was clearly a major undertaking, as measurements of the composition of modified garden soils reveal. To modify one hectare of soil required the digging, transport in flax baskets, and spreading of $1300 \mathrm{~m}^{3}$ of sand and gravel. ${ }^{32}$ To do that for 3000 ha would have required four million $\mathrm{m}^{3}$ being dug up and distributed. To appreciate how much that is, the floor slab for a $140 \mathrm{~m}^{2}$ house will need about 
$16 \mathrm{~m}^{3}$ of sand, gravel and cement, so $4,000,000 \mathrm{~m}^{3}=$ about 250,000 house slabs, or four times the volume of the Clyde dam. Of course, only a proportion of the gardens were in use at once, partly because they seem to have been built over a period extending from the sixteenth to the eighteenth centuries, and also because they were swiddens, that is, gardens used for several years until the soil fertility declined, then abandoned for perhaps 7-20 years to recover. ${ }^{33}$ Even so, the Waikato gardens, like those in the Tamaki district, represent a scale of activity that is an order of magnitude greater than any in central New Zealand.

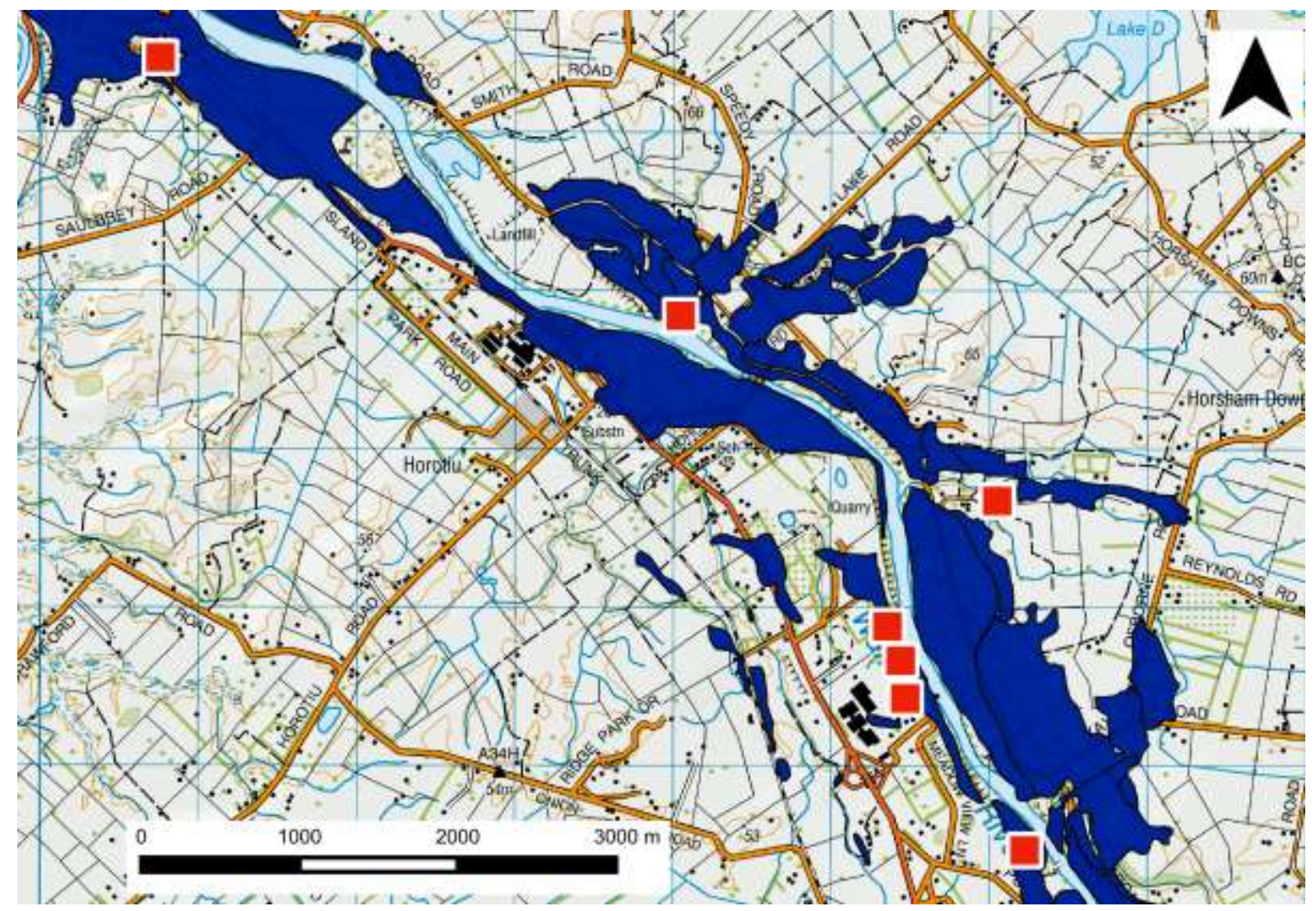

Figure 4: Dark areas show extensive distribution of soils made by Māori for gardening in part of the Horotiu district of the middle Waikato basin. Squares show locations of pa sites (courtesy of Warren Gumbley).

It is probable that other areas were gardened on a similar scale in inland Hauraki and elsewhere. As yet data are few, but recent research by Caroline Phillips in the inland western Bay of Plenty is perhaps indicative. ${ }^{34}$ She began with the puzzle of numerous storage pits in the landscape but few or no reported gardens. Now, by judicious excavation of a small plateau around which were nine clusters of storage pits, she has found nine gardens, about one ha in total, and some 660 hangi features. The gardens disclosed neat rows of planting pits and soil modification, as in the Waikato, and it is very likely that there was a similar intensity of gardening in the region.

The powerful expansion of gardening in northern NZ during the middle period, particularly in contrast with failing horticulture in central New Zealand begs the question of difference - what drove northern gardening? Leaving aside climatic tolerance, the answer, one might say, lies in the soil. Whether or not the movement of gardening into the northern interior around AD 1500 was a response to deteriorating coastal climates, especially higher winds and 
rainfall — and the Waikato Basin is certainly drier than the Waikato coast - the move was fortunate because it took ambitious gardeners to an especially favourable type of soil.

Soils derived from tephra occur over about $40 \%$ of the North Island. The two main groups are pumice soils (15\% of the North Island) and allophanic soils (12\% of the North Island). Pumice soils lying to the east and northeast are formed on very young, weakly consolidated sediments that are low in clay content and deficient in major nutrient and trace elements. Allophanic soils are mainly toward the west. They formed on fine-grained tephra layers in Taranaki, south and west of the Volcanic Plateau, and through the King Country, Waikato and western Bay of Plenty. Smaller areas are found on basaltic scoria cones in Auckland and Northland. The soils are deep, mature and mostly 10,000 to 25,000 years old..$^{35}$ They are named from their dominant clay mineral, allophane, which occurs as nanocrystalline particles (onemillionth of a millimeter in diameter) of relatively huge surface area (one teaspoon of allophane $=800 \mathrm{~m}^{2}$ of surface area), which facilitates a high capacity for soil nutrient exchange with plants. Allophanic soils have high organic carbon content, good aeration and water retention, and they are free draining, even after heavy rain. Easy to dig and weed, and distributed across smooth, tephra-mantled landscapes they are described by David Lowe as "supreme in New Zealand for food production." 36 All the areas that have extensive evidence of horticultureinland Bay of Islands, Tamaki, South Auckland, western Bay of Plenty and Taranaki-have allophanic soils, usually as the dominant type. Mid-sequence northern Māori were, we might say, "allophanatics."

The productivity of pre-European kumara gardens on allophanic soils is not yet known, but experimental data from 7 years of trial plots in sandy loams either side of Cook Strait suggest some estimates to conjure with. The experimental plots averaged 12 tonnes of kumara per hectare, which is three to four times earlier estimates of pre-European kumara yield, and close to the modern global average of 13 tonnes. ${ }^{37}$ Given an average yield of $865 \mathrm{kcal} / \mathrm{kg}$ of kumara and a $3000 \mathrm{kcal} / \mathrm{day}$ requirement for an adult, the kumara produced from one ha would provide almost 3500 person/days of an exclusively kumara diet, or 4.6 months of food for 25 people. If the ratio of gardens in use to those left fallow was 1:5, as Kevin Jones established from a detailed analysis of eighteenth-century gardening at Anaura bay, East Coast, then 600 ha of the central Waikato gardens would be in use at any one time, and they could have produced enough food for 15,000 people for the winter, May to September. ${ }^{38}$ This is a crude estimate, but it suggests at least that kumara production could have made a very substantial difference in population carrying capacity during the middle period in northern New Zealand.

The overall demographic significance of gardening can be estimated broadly from the mean population density of Māori by about 1800. In non-horticultural southern New Zealand there were only 0.02 people per $\mathrm{km}^{2}$, in central New Zealand about 0.25 people per $\mathrm{km}^{2}$, and 1.0 person per $\mathrm{km}^{2}$ north of the fortieth parallel. If the population density reached in southern and central New Zealand approximates that which was possible for Māori in the absence of agriculture, then higher densities to the north represent, although not wholly, the demographic

boost of cultivating kumara in an environment where sources of edible starch were otherwise relatively scarce. In fact, those that did exist were more common in the north than elsewhere. Large-scale northern horticulture, relatively immune to climate change and intricately entwined with population growth, was the engine of cultural transition in the middle phase, but it had a very narrow resource base; it was indeed virtually a monoculture of kumara cultivation, and as such it was at risk of substantial fluctuation in production.

\section{Emergent Changes}

I come now to the emergent effects of northern horticulture and demography. By emergent, I mean behaviour that can be seen in a general way as arising from the new economic and demographic landscape but which cannot be argued as a necessary result of it. Migration away 
from the centre of growth, which is my first example, is emergent in the sense that it may be a response to competition but it is only one of several possibilities; others were to form alliances or to fight, and in fact, the traditions indicate that amongst related groups some took one option and some another.

Nevertheless, migration is one of the most characteristic features of the middle phase, and a dominating theme in the traditions of that time. ${ }^{39} \mathrm{I}$ just want to make a few points here. Most group migrations began in the early sixteenth century. Within the main horticultural region, migrations were mostly short and in varied directions. Deliberate Tainui migration inland began about 1520 from Kawhia into the Waikato valley, and by 1550 it had moved further east, north and south. Outside the main horticultural area, most of the migrations also began around 1500-1550. Their common origin was in the Hawkes Bay region and they went southwest ending up in Wairarapa, Horowhenua or Wellington before some departed for the South Island. Different groups may have had different motivations for migrating, but the common time horizon in the sixteenth century suggests a general affect as well. Perhaps a rising population was reaching the point where re-distribution was becoming necessary. Perhaps the combination of a sudden drop in annual temperature about 1500 and the very wet conditions prevailing then in the eastern North Island affected groups on the horticultural margins the most, initiating migration. Research is needed on the age and area distributions of horticulture in Hawkes Bay.

A second emergent feature, I suspect, was that large-scale northern horticulture involved new labour relations, notably slavery. Unfortunately we know almost nothing about slavery prior to European arrival, except that it existed. An apparent increase in slavery in the earlynineteenth century is suggested as a response to the need for additional labour to produce the potatoes that were necessary for trade in muskets. Whether that was actually so is debated, but the case is plausible enough to wonder if slavery might also have surged in a cognate way during the middle phase. ${ }^{40}$ There are theoretical grounds to think so. A new model of slavery indicates that it is a transitional phenomenon of relationships between property rights and labour relations. ${ }^{41}$ Slavery is uncommon in low-density forager or low-level farming societies at one extreme, or in high density rural settlement with elite ownership at the other extreme. It emerges most commonly in intermediate situations where land productivity is high enough to encourage vigorous expansion, but population density is only moderate, as for example when colonizing populations occupy lands with extensive potential for development but have limited access to free labour, and it tends to decline as availability of free labour increases.

During the middle phase in northern New Zealand, there was movement on to soils well suited to large-scale gardening including production of surplus for redistribution and exchange, but the extent of the allophanic soils greatly exceeded the labour available to use them, and the labour required in modifying the soils alone must have been prodigious. Recourse to slavery was a potential solution. It is possible that slave-raiding of groups living around the margins of the main horticultural areas was an important factor in migrations during the middle phase. On the southern margins, especially, it must have been obvious that the gradients of population density and military power ramped up to the north, and that the only choice of movement was southward. As the children of a Māori slave to a free parent became themselves free, the capacity to produce slaves by breeding was more limited than was the case in slavery generally, and raiding must have been correspondingly more frequent. This is a proposition almost impossible to test archaeologically, or through traditional records, which seldom refer to slavery, but it might become amenable to genetic data. In Iceland, for instance, an unusually strong genetic signal for Celtic ancestry amongst women, relative to men, is a potential sign of differential coercion, and one that, in some way, might eventually be picked up regional patterns of Māori genetics. 
Changes in group size and organisation for defence may have begun to emerge in northern New Zealand in the middle phase. Jeff Sissons has proposed a reformation of tribal organization in the North Island in the eighteenth century in which lineages that subsequently dominated evolution into iwi came to the fore. ${ }^{42}$ Conditions that could have given rise to that phenomenon might be detected in some middle phase data. In the Waikato basin, not only the large garden sites, but swamp pa and other kinds of sites all date initially to the early-sixteenth century, indicating that movement into the district occurred as a substantial migration. In addition, current survey data indicate that the number of storage pits is substantially fewer than the area of gardens would need. ${ }^{43}$ This might reflect an archaeological difficulty in locating storage pits in the district ${ }^{44}$ or possibly that some of the produce was being taken elsewhere, with both the distance to consumers and the safety of transport indicating the cooperation, and perhaps organization, of multiple communities in the system as a whole.

Research on the chronological dispersal of pa sites by Geoff Irwin suggests a similar scale of migration by large groups. On the southern end of North Kaipara Head, 20 pa sites are set in a strategic pattern and they were all built at the same time in the eighteenth century, indicating either a large group migration, or a concerted response to external threat by a large resident group. On Ponui Island, in the Hauraki Gulf, the distribution of pa built in the earlysixteenth century indicates a similarly short span of pa building and a strategic defensive system for the island as a whole. ${ }^{45}$ Nigel Prickett's work on pa landscapes in Taranaki produced comparable evidence. ${ }^{46}$ In other words, even in the middle phase, many pa were built not as independent places of defence but in corporate arrangements designed to protect hundreds of people and their resources at a time.

Lastly, and most conspicuously, the middle period was the time when pa construction began, around 1500-1550. ${ }^{47}$ The role of pa sites has been interpreted variously since they were first seen from the sea by outsiders, in 1769, on which occasion Tupaia, the Society Islands scholar on the Endeavour, suggested that they were religious structures while Cook declared them to be forts. I think both were correct. Pa sites reflected the vulnerability of people and their food stores at a time of increasing population density, but it was not just that. Throughout the Pacific, in populations of much higher density than in New Zealand, and more strongly dependent upon agriculture, there was frequent warfare in the scarcity or absence of forts; Hawaii, Tahiti, and highland New Guinea are examples. One possible reason for that might be an important difference in the seasonality of production. In the tropical Pacific most root crops would produce twice a year or more often and there was, in addition, a wide range of additional food plants, many cropping all year round. Periodic warfare might result in some crop or store losses, but far from all. In temperate New Zealand, however, horticulture - for the most partmeant producing one crop of kumara each year at a predictable time. Protection of that single harvest for food and seed tubers was consequently more critical, and became increasingly so as reliance upon horticulture developed in northern New Zealand during the middle phase and later. It might be that factor which, more than any others, created a distribution of pa sites that maps so precisely the distribution of horticulture (Figure 5). Critical seasonality of production in temperate New Zealand may have been an important factor in the origin of pa but, as Geoffrey Irwin argued, it is not just about the vegetables; identity, status and military strength were also on display. ${ }^{48}$

In addition, pa might also be considered as religious or ritual features. New Zealand was colonized before megalithic marae or ahu developed in East Polynesia but small, paved-stone ritual features existed in East Polynesia at the time of migration to New Zealand, and there are similar paved features in a number of early Māori sites. Such relatively inconspicuous ritual sites might have eluded archaeological notice, or been destroyed at the time of conversion to Christianity. But it can be argued also that while ritual sites might once have been safely dispersed in group territories, the tensions arising from growing population density on and 
around horticultural lands created an increasing need for groups to protect their ritual assetsancestor carvings, godsticks, bundled bones and other sacred things. The pa became a sanctuary for clan spirits as much as it offered safe storage and protection for people. ${ }^{49}$

These propositions, and others, about the history, functions and significance of pa, need systematic archaeological attention; the largest, most intricate and most numerous (Figure 5) of our pre-European structural sites are still conspicuously under-investigated.

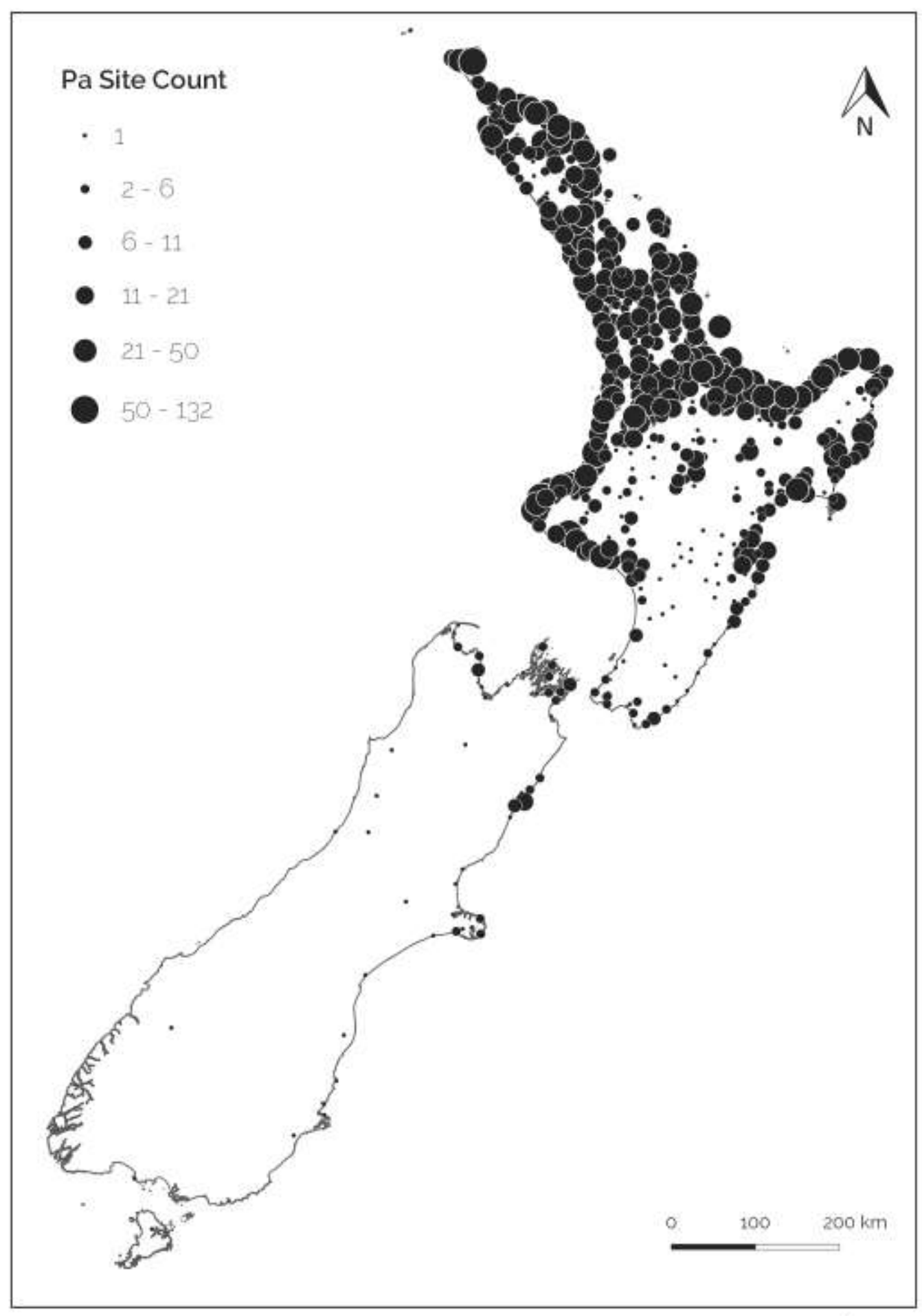

Figure 5: Distribution of pa sites in New Zealand showing heavy concentration in horticultural districts of northern New Zealand. 


\section{Conclusions:}

In reflecting on what I have been able to say about these transitions I cannot claim to have moved us materially closer to understanding the middle phase of Māori archaeology in a way that offers a coherent narrative of culture change from beginning to end. Rather, I have emphasized some salient points in working towards that objective. I have drawn attention to the existence of the middle phase as wholly within the period of the Little Ice Age, observing that this blighted the southern region and stripped horticulture out of most of the central region at a time when, in almost any demographic model, we would expect vigorous population growth to have been occurring. Climate change in the middle phase made about $70 \%$ of the area of New Zealand worse off and less populous. As a result, transition, and indeed the population and culture of the late phase, or Classic Māori, was almost entirely a northern story.

After about AD 1500 the landscape of economic opportunity was tilted sharply up to the north. Northern horticulture, I have suggested, was ramped up on substantial expanses of allophanic soils to form large-scale enterprises, in effect if not in management. Population growth must have been rapid, even if it was also vulnerable to boom and bust fluctuations, and it is probable that effective group sizes became larger and corporately active in acquiring territory, alongside a rise in warfare and perhaps a surge in slavery, all underlined by the innovation of pa sites. In a way, the triumph of the north, so to speak, was completed by the southward migration of northern groups, especially from the East Coast and Hawkes Bay, to exert their mana over most of central and southern New Zealand.

The middle phase was a time of considerable change in fundamental ways and we need to understand it much better than we do, both for the light it casts upon the long-term development of Māori society as a whole, and for the significance of transition in thinking about the past. Without a vigorously inquisitive, data-based archaeology of transition constituting the null hypothesis, there is a temptation to construct change as abrupt or monolithic and possibly explicable by idiosyncratic mechanisms - which is not to say that those, such as later Polynesian migrations to New Zealand, meteor strikes or tsunamis,${ }^{50}$ are necessarily improbable explanations, but only that unless they are exposed to comparison with an archaeology of transition they might be accepted prematurely. Finally, research on cultural transition connects Māori archaeology as a highly visible and independent witness to the global phenomenon of human adaptation to new and volatile landmasses, with all the issues that involves: extinctions, landscape change, colonization demography, development of agriculture, rise of warfare, and the dynamics of societal change. In making, or perhaps re-making, the Māori middle ages we have a big task in front of us, but it is an important one.

Acknowledgements: I thank the Stout Trust for the J. D. Stout Fellowship and Lydia Wevers and the Stout Centre staff for their collegial support and kindness. Warren Gumbley, Bruce McFadgen, and Caroline Phillips generously allowed me access to unpublished information, and I thank them, together with Geoff Irwin and Jeff Sissons, for their thoughtful comments. My thanks to Anna Green for editorial assistance and to Debbie Levy for setting the manuscript. 
${ }^{1}$ Jack Golson, "Culture Change in Prehistoric New Zealand," in Anthropology in the South Seas: Essays Presented to H. D. Skinner, ed. J. D. Freeman and W. R. Geddes (New Plymouth: Avery, 1959), 29-74.

${ }^{2}$ Roger Green and Wilfred Shawcross, "Cultural Sequence in the Auckland Province," NZAA Newsletter 5 (1962): 210-22; Janet Davidson, "New Zealand Prehistory," in Advances in World Archaeology, ed. F. Wendorf, volume 4 (New York: Academic Press, 1985), 239-91.

${ }^{3}$ F. W. Shawcross, "An Archaeological Assemblage of Maori Combs," Journal of the Polynesian Society 73 (1964): 382-98; Sidney Moko Mead, "Ka Tupu Te Toi Whakairo ki Aotearoa: Becoming Maori Art," in Te Maori: Maori Art from New Zealand Collections, ed. S. M. Mead (Auckland: Heinemann,1984), 64.

${ }^{4}$ Janet Davidson, The Prehistory of New Zealand (Auckland: Longman, 1984), 225; Emma Brooks, Chris Jacomb and Richard Walter, "Interim Report on Archaeological Investigations at Kahukura (G47/128), Southland," Southern Pacific Archaeological Research report (Dunedin, 2010).

5 Jack Golson, "Old Guards and New Waves: Reflections on Antipodean Archaeology 1954-1975," Archaeology in Oceania 21 (1986): 2-12.

${ }^{6}$ Douglas Yen, "The Adaptation of Kumara by the New Zealand Maori," JPS 70 (1961): 338-48.

${ }^{7}$ Roger Green, A Review of the Prehistoric Sequence of the Auckland Province (Dunedin: University Book Shop, 1970); Foss Leach and Helen Leach, ed., Prehistoric Man in Palliser Bay, National Museum of New Zealand Bulletin 21 (Wellington: National Museum of New Zealand, 1979).

${ }^{8}$ Atholl Anderson, "The Chronology of Colonization in New Zealand," Antiquity 65 (1991): 767-95. Using early radiocarbon data, Wilfred Shawcross suspected colonization had occurred about the $12^{\text {th }}$ century A.D. See his "Archaeology with a Short, Isolated Time-scale: New Zealand," World Archaeology (1969): 184-99.

${ }^{9}$ Foss Leach, "The Prehistory of the Southern Wairarapa," Journal of the Royal Society of New Zealand 11 (1981): 11-33.

${ }^{10}$ Jim Renwick and David Thompson, "The Southern Annular Mode and New Zealand Climate," Water and Atmosphere 14 (2006): 24-25; Basil Gomez, Lionel Carter, Alan R. Orpin, et al., "ENSO/SAM Interactions During the Middle and Late Holocene," The Holocene 22 (2011): 23-30. ${ }^{11}$ J. W. Kidson, "An Analysis of New Zealand Synoptic Types and their Use in Defining Weather Regimes," International Journal of Climatology 20 (2000): 299-316; A. M. Lorrey, A. M. Fowler and J. Salinger, "Regional Climate Regime Classification as a Qualitative Tool for Interpreting Multi-proxy Paleoclimate Data Spatial Patterns," Palaeogeography, Palaeoclimatology, Palaeoecology 253 (2007): 407-33.

${ }^{12}$ Heidi Anne Roop, "Late-Holocene Climate Variability in Southern New Zealand: A Reconstruction of Regional Climate from an Annually Laminated Sediment Sequence from Lake Ohau" (doctoral thesis in Geology, Victoria University of Wellington, 2015).

${ }^{13}$ David B. McWethy, Cathy Whitlock, Janet M. Wilmshurst, et al., "Rapid Landscape Transformation in the South Island, New Zealand, Following Initial Polynesian Settlement," Proceedings of the National Academy of Sciences USA 14 (2010): 21343-48.

${ }^{14}$ Atholl Anderson, Judith Binney and Aroha Harris, Tangata Whenua: An Illustrated History (Wellington: Bridget Williams Books, 2014), 85.

${ }^{15}$ Atholl Anderson and Ian Smith, "Shag Mouth as an Early Maori Village," in Shag River Mouth: The Archaeology of an Early Southern Maori Village, ed. Atholl Anderson, Brian Allingham and Ian Smith (Canberra: Australian National University Press, 1996), 276-91.

${ }^{16}$ Adrian J. Challis, "The Nelson-Marlborough Region: An Archaeological Synthesis," New Zealand Journal of Archaeology 13 (1991): 101-42; Adrian J. Challis, Ko Pakihi Whakatekateka o Waitaha: The Archaeology of Canterbury in Maori Times, Science and Research (Department of Conservation) 89 (Wellington: Department of Conservartion, 1995); Ian Barber, "Crops on the Border: The Growth of Archaeological Knowledge of Polynesian Cultivation in New Zealand," in Change Through Time: 50 Years of New Zealand Archaeology, ed. Louise Furey and Simon Holdaway (Auckland: New Zealand Archaeological Assocaition, 2004), 169-92; Ian Barber, "Diffusion or Innovation? Explaining Extensive Lithic Cultivation Fields on the Southern Polynesian Margins," World Archaeology 42 (2010): 75-90. 
${ }^{17}$ Ian Barber, "Molluscan Mulching at the Margins: Investigating the Development of South Island Maori Variation on Polynesian Hard Mulch Agronomy," Archaeology in Oceania 48 (2013): 40-52.

${ }^{18}$ Bruce McFadgen, Archaeology of the Wellington Conservancy: Kapiti-Horowhenua. A Prehistoric and Palaeoenvironmental Study (Wellington: Department of Conservation, 1997); Bruce McFadgen, Archaeology of the Wellington Conservancy: Wairarapa (Wellington: Department of Conservation, 2003).

${ }^{19}$ Foss Leach, "The Prehistory of the Southern Wairarapa"; J. Rutland, "On the Ancient Pit Dwellings of the Pelorus District, South Island, N.Z." JPS 6 (1897): 77-84.

${ }^{20}$ Kari N. Bassett, Hamish W. Gordon, David C. Nobes and Chris Jacomb, "Gardening at the Edge: Documenting the Limits of Tropical Polynesian Kumara Horticulture in Southern New Zealand," Geoarchaeology 19 (2004):185-218.

${ }^{21}$ E. R. Cook, J. G. Palmer and B. I. Cook et al., "A Multi-millennial Palaeoclimatic Resource from Lagarstrobos Colensoi Tree-rings at Oroko Swamp, New Zealand," Global and Planetary Change 33 (2002): 209-20.

${ }^{22}$ Anthony Lorrey, Paul Williams, Jim Salinger, et al., "Speleothem Stable Isotope Records Interpreted with a Multi-proxy Framework and Implications for New Zealand Palaeoclimate Reconstruction," Quaternary International 187 (2008): 52-75; P. W. Williams, D. N. T. King, J-X. Zhao and K. D. Collerson, "Speleothem Master Chronologies: Combined Holocene ${ }^{18} \mathrm{O}$ and ${ }^{13} \mathrm{C}$ Records from the North Island of New Zealand and Their Palaeoenvironmental Interpretation," The Holocene 14 (2004): 194-2008.

${ }^{23}$ Brian Fagan, The Little Ice Age: How Climate Made History 1300-1850 (New York: Basic Books, 2000).

${ }^{24}$ For example: Patrick V. Kirch, "Re-thinking East Polynesian Prehistory," JPS (1986): 9-40; Adele L. H. Whyte, Stephen J. Marshall and Geoffrey K. Chambers, "Evolution in Polynesia," Human Biology 77 (2005): 157-77. For an alternative perspective, see Douglas G. Sutton and Maureen A. Molloy, "Deconstructing Pacific Palaeodemography: A Critique of Density-dependent Causality," Archaeology in Oceania 24 (1989): 31-36.

${ }^{25}$ B. G. McFadgen, F. B. Knox and T. R. L. Cole, "Radiocarbon Calibration Curve Variations and their Implications for the Interpretation of New Zealand Prehistory," Radiocarbon 36 (1994): 221-36.

${ }^{26}$ J. Stephen Athens, "Prehistoric Population Growth on Kosrae, Eastern Caroline Islands," in The Growth and Collapse of Pacific Island Societies: Archaeological and Demographic Perspectives, ed. Patrick V. Kirch and Jean-Louis Rallu (Honolulu: University of Hawai'i Press, 2007), 257-27; Patrick V. Kirch, "Like Shoals of Fish': Archaeology and Population in Pre-contact Hawai'i," in Growth and Collapse, ed. Kirch and Rallu, 52-107.

${ }^{27}$ See McFadgen, Knox and Cole, "Radiocarbon Calibration Curve," for the New Zealand curve; Bay of Plenty date curve in Garry Law, Archaeology of the Bay of Plenty (Wellington: Department of Conservation, 2008).

${ }^{28}$ Stephen Shennan, Sean S. Downey, Adrian Timpson et al., "Regional Population Collapse Following Initial Agriculture Booms in Mid-Holocene Europe,' Nature Communications 4 (2013), Doi:10.1038/ncomms3486.

${ }^{29}$ D. G. Sutton, L. Furey and Y. Marshall, ed., The Archaeology of Pouerua (Auckland: Auckland University Press, 2003); Susan Bulmer reports that medium sized volcanic fields averaged 300-500 ha, suggesting 7000-10,000 ha of volcanic soils available: Susan Bulmer, "Prehistoric Settlement Patterns in the Volcanic Fields of Taamaki: A Review," Man and Culture in Oceania 3 (1987): 133-56. But the areal distribution of garden features in them varies, e.g. for the Wiri area: 280 ha (see Helen Leach, "The Significance of Early Horticulture in Palliser Bay," 241-49), and 60 ha (see Louise Furey, Maori Gardening: An Archaeological Perspective (Wellington: Department of Conservation, 2006), 60).

${ }^{30}$ W. Gumbley, T. F. G. Higham and D. J. Lowe, "Prehistoric Horticultural Adaptation of Soils in the Middle Waikato Basin: Review and Evidence from S14/201 and S14/185, Hamilton," New Zealand Journal of Archaeology 25 (2003): 5-30.

${ }^{31}$ Matthew Campbell, Cambridge Section of the Waikato Expressway: Archaeological Desktop Study (Auckland: CFG Heritage, 2012); Warren Gumbley and Malcolm Hutchinson, Pre-European Maori Garden Sites in Waipa District: An Assessment of the State of the Resource (Hamilton: W. Gumbley Ltd Archaeologists, 2013).

${ }^{32}$ Gumbley et al., "Prehistoric Horticultural Adaptation of Soils." 
${ }^{33}$ Warren Gumbley and Andrew Hoffmann, The Archaeology of Pre-European Maori Horticulture at Horotiu: The Investigations of S14/194 and S14/195 (Hamilton: W. Gumbley Ltd Archaeologists, 2013).

${ }^{34}$ Caroline Phillips, "Joining the Dots: Discovering Maori Gardens in the Bay of Plenty," presentation to the New Zealand Archaeological Association Conference, Blenheim, 23 June 2016, and subsequent correspondence.

${ }^{35}$ D. J. Lowe, ed, Guidebook for Pre-conference North Island Field Trip A1: Ashes and

Issues, 28-30 November, 2008 (Christchurch: New Zealand Society of Soil Science, 2008); D. J.

Lowe, "Introduction to the Landscapes and Soils of the Hamilton Basin," in Guidebook for Preconference North Island, New Zealand Volcanoes to Oceans field tour, 27-30 July, 2010, D. J.

Lowe, V. E. Neall, M. Hedley et al., Soil and Earth Sciences Occasional Publication 3 (Palmerston North: New Zealand Society of Soil Science, 2010), 1.24-61; R. Parfitt, "Why are Volcanic Ash Soils Unique?" Soil Horizons 3 (1999): 8-9.

${ }^{36}$ D. J. Lowe, Guidebook 2008, 20.

${ }^{37}$ Mike Burtenshaw and Graham Harris, "Experimental Archaeology Gardens Assessing the Productivity of Ancient Maori Cultivars of Sweet Potato, Ipomoea Batatas [L.] Lam. in New Zealand," Economic Botany 61 (2007): 235-45.

${ }^{38}$ Kevin L. Jones, “'In Much Greater Affluence': Productivity and Welfare in Maori Gardening at Anaura Bay, October 1769," JPS 98 (1989): 49-75.

${ }^{39}$ Anderson, Binney and Harris, Tangata Whenua, 113-19.

${ }^{40}$ Hazel Petrie, Outcasts of the Gods: The Struggle over Slavery in Maori New Zealand, (Auckland: Auckland University Press, 2015), 123-28.

${ }^{41}$ Nils-Petter Lagerlöf, "Slavery and Other Property Rights," The Review of Economic Studies 76 (2009): 319-42.

${ }^{42}$ Jeff Sissons, "Rethinking Tribal Origins," JPS 97 (1988): 199-204.

${ }^{43}$ Campbell, Cambridge Section of the Waikato Expressway, 56-60.

${ }^{44}$ Pits are discovered in the Bay of Plenty by their association with visible deposits of midden, but midden is very scarce in the inland Waikato (Warren Gumbley, personal communication).

${ }^{45}$ Geoffrey Irwin, Land, Pa and Polity: A Study Based on the Maori Fortifications of Pouto, New Zealand Archaeological Association Monograph 15, (Auckland: New Zealand Archaeological Association, 1985); Geoffrey Irwin, "Wetland Archaeology and the Study of Late Maori Settlement Patterns and Social Organization in Northern New Zealand," JPS 122 (2013): 311-32.

${ }^{46}$ N. J. Prickett, "Maori Fortifications of the Tataraimaka District, Taranaki," Records of the Auckland Institute and Museum 19 (1982): 1-52; N. J. Prickett, "Maori Fortifications of the Okato District, Taranaki," Records of the Auckland Institute and Museum 20 (1983): 1-39.

${ }^{47}$ M. Schmidt, "The Commencement of Pa Construction in New Zealand Prehistory," Journal of the Polynesian Society 105 (1996): 441-51.

${ }^{48}$ Geoffrey Irwin, "Creation Myths and the Origin of Pa," NZAA Newsletter 25 (1982): 258-67.

${ }^{49}$ Atholl Anderson, "Monumentality and Ritual Behaviour in South Polynesia," in Studies in Global Archaeology 24, ed. H. Martinsson-Wallin and T. Thomas (Uppsala: University of Uppsala, 2014), 273-96.

${ }^{50}$ D. H. Abbott, P. Biscaye, J. Cole-Dai, and D. Breger, "Evidence from an Ice Core of a Large Impact Circa 1443 A.D.," American Geophysical Union (2005), abstract PP31C-05; Bruce McFadgen, Hostile Shores: Catastrophic Events in Prehistoric New Zealand and their Impact on Maori Coastal Communities (Auckland: Auckland University Press, 2007); J. Goff, B. G. McFadgen, C. Chague-Goff and S. L. Nichol, "Palaeotsunamis and their Influence on Polynesian Settlement," The Holocene 22 (2012): 1067-69. 